\title{
Akut coronariaszindróma miatt 2015-ben kezelt betegeink lipidcsökkentő terápiája
}

\author{
Márk László dr. ${ }^{1}$ - Nagy Mária dr. ${ }^{1}$ - Dani Győző dr. ${ }^{2}$ - Baranyai Csaba dr. ${ }^{1}$ \\ Borbély Marianna dr. ${ }^{3}$ - Katona András dr. ${ }^{1}$ - Jambrik Zoltán dr. ${ }^{1}$ \\ ${ }^{1}$ Békés Megyei Központi Kórház Pándy Kálmán Tagkórháza, Gyula \\ ${ }^{2}$ Városi Kórház, Orosháza \\ ${ }^{3}$ Békés Megyei Központi Kórház Dr. Réthy Pál Tagkórháza, Békéscsaba
}

\begin{abstract}
Bevezetés: A jelenleg érvényes prevenciós irányelvek nagy hangsúlyt fektetnek az akut coronariaszindrómán (ACS) átesett betegek lipidcsökkentő kezelésére.

Célkitüzés: Annak vizsgálata, hogy a hemodinamikai laborral rendelkező hazai megyei kórházban az ACS miatt kezelt betegek hazaengedésekor milyen arányban alkalmazzuk az irányelvek által előírt nagy dózisú statint, valamint hogy az invazív beavatkozás utáni első évben miként alakulnak a betegek LDL-koleszterin-szintjei (LDL-C) és a célértékek elérése.

Módszer: A kórházi adatbázisokból történő retrospektív adatgyưjtés a 2015. évben ACS miatt szívkatéteres intervención átesett betegek elbocsátási terápiájáról és az azt követő egy év kezeléséről és lipidértékeiről.

Eredmények: ACS miatt 2015-ben 454 beteg esett át intervención, kórházi elbocsátáskor a betegek több mint 9/10-e nagy dózisú statint (több mint 80\%-uk 40 mg rozuvastatint), vagy annak megfelelő kombinációt kapott. 154 beteg esetében találtunk féléves lipideredményt, az LDL-C mediánja $1,9 \mathrm{mmol} / 1$ volt, az $1,8 \mathrm{mmol} / 1$ célértéket $48,7 \%$ érte el. Egyéves vizsgálati eredményt 292 beteg esetében találtunk (az elhalálozottakat és a nem az ellátási területünkön élőket leszámítva az összes beteg 73\%-a), az LDL-C mediánja 2,0 mmol/1, a célérték elérési aránya pedig 37,3\% volt. Nem találtunk szignifikáns eltérést a három ACS-forma, valamint a férfiak és a nők eredményei között.

Következtetések: Az ellenőrzésekre járó revaszkularizált betegek körében elfogadhatónak találtuk a lipidcsökkentő kezelés minőségét, de nagyobb hangsúlyt kell helyezni arra, hogy a jelenlegi kétharmadhoz képest több betegen történjenek meg a kontrollvizsgálatok.
\end{abstract}

Orv Hetil. 2018; 159(12): 478-484.

Kulcsszavak: akut coronariaszindróma, rizikófaktorok, cardiovascularis prevenció, statinok, irányelvek

\section{Lipid-lowering therapy of patients suffering from acute coronary syndrome in a Hungarian county hospital in 2015}

Introduction: The actual guidelines of cardiovascular prevention lay special emphasis on the lipid-lowering therapy of patients suffering from acute coronary syndrome (ACS).

Aim: To evaluate the occurrence of high-intensity statin therapy, recommended by guidelines, at discharge in a Hungarian county hospital with hemodynamic laboratory in patients who underwent percutaneous intervention, furthermore the LDL-cholesterol (LDL-C) levels and goal attainment rate in the first year.

Method: Retrospective data collection from the hospital database regarding the therapy at discharge and the lipid levels in the year following the intervention due to ACS in 2015.

Results: Due to ACS event, 454 patients had coronary intervention in 2015 , at discharge more than $90 \%$ of them received high-intensity statin (more than $80 \%$ rosuvastatin, $40 \mathrm{mg}$ ) or corresponding combination therapy. In 154 cases we found half-year lipid results; the median of LDL-C was $1.9 \mathrm{mmol} / \mathrm{L}$, the $1.8 \mathrm{mmol} / \mathrm{L}$ target value attainment rate was $48.7 \%$. Results after one year were found in 292 cases ( $73 \%$ without the deceased and foreign patients); the LDL-C median proved to be $2.0 \mathrm{mmol} / \mathrm{L}$, the target level attainment rate was $37.3 \%$. There was no significant difference between the results of patients from the three different ACS forms and between those of men and women. Conclusions: The lipid lowering therapy of the revascularized patients who come back for medical visits is acceptable, but greater emphasis has to be laid on increasing the rate of controlled patients compared to the present two-thirds. 
Keywords: acute coronary syndrome, risk factors, cardiovascular prevention, statins, guidelines

Márk L, Nagy M, Dani Gy, Baranyai Cs, Borbély M, Katona A, Jambrik Z. [Lipid-lowering therapy of patients suffering from acute coronary syndrome in a Hungarian county hospital in 2015]. Orv Hetil. 2018; 159(12): 478-484.

(Beérkezett: 2017. december 11.; elfogadva: 2017. december 29.)

\begin{abstract}
Rövidítések
ACS = (acute coronary syndrome) akut coronariaszindróma; $\mathrm{AMI}=$ (acute myocardial infarction $)$ akut myocardialis infarctus; DYSIS = Dyslipidemia International Study; EAS $=($ European Atherosclerosis Society) Európai Atherosclerosis Társaság; $\quad \mathrm{ESC}=($ European Society of Cardiology) Európai Kardiológusok Társasága; IQ = (interquartile) interkvartilis; ISAP = instabil angina pectoris; ISZB = ischaemiás szívbetegség; LDL-C = LDL-koleszterin; NSTEMI = nem ST-elevatiós myocardialis infarctus; PCI = percutan coronariaintervenció; $\mathrm{SD}=$ standard deviáció; STEMI = ST-elevatiós myocardialis infarctus
\end{abstract}

A Framingham Study eredményei alapján 1964-ben közölték azt a megfigyelést, hogy a koleszterinnek fontos szerepe van az atherosclerosis kialakulásában [1]. Az utóbbi évtizedek klinikai vizsgálatai sokszorosan igazolták az LDL-koleszterin (LDL-C) csökkentésének kedvező hatását a cardiovascularis események gyakoriságára. Sajnálatos, hogy mindezek ellenére a koleszterinszint csökkentésének fontossága sem a lakosságban, sem az orvosok értékrendjében nem áll az őt megillető helyen. Az Európai Atherosclerosis Társaság (EAS) 2017. áprilisi szakértői állásfoglalása az időnként fellángoló statin- és koleszterinellenesség hatására összegezte azokat a bizonyítékokat, amelyek az LDL-C és az atherosclerosis kapcsolatát támasztják alá. Az epidemiológiai vizsgálatok, a mendeli randomizációs vizsgálatok és a randomizált klinikai tanulmányok eredményei összesen több mint 2 millió beteg 20 millió betegév megfigyelése és több mint 150 ezer lezajlott cardiovascularis eseménye alapján ismételten egyértelmúen igazolták, hogy lineáris összefüggés van az LDL-C értéke és az atherosclerosis kockázata között [2].

$\mathrm{Az}$ LDL-C csökkentésének elsőként választandó gyógyszerei minden terápiás ajánlásban a statinok, egy sikeres, nagyon hatékony, sok ember életét meghosszabbító és megmentő gyógyszercsoport. Az európai és a magyar irányelvek a lipidcsökkentő kezelésben a célértékek elérését írják elő [3, 4]. Az Európai Kardiológusok Társasága és az Európai Atherosclerosis Társaság (ESC/ EAS) 2016 augusztusában megjelent dyslipidaemiakezelési ajánlásaiban új elem, hogy igen nagy kockázat esetén, az 1,8 mmol/1 LDL-C-célérték megtartása mellett, ha a kiindulási, kezelés nélküli LDL-C 1,8 és 3,5 mmol/1 között van, akkor nem elég az 1,8 mmol/1 szint elérése, hanem az indulásihoz képest 50\%-os csökkentés szükséges. Hasonlóképpen, nagy cardiovascularis kockázat esetén, ha a beteg kezdeti LDL-C-je 2,6 és 5,2 mmol/l között van, akkor nem a 2,6 mmol/l elérése javasolt, hanem az 50\%-os csökkentés [4].

Az új lipidajánlásban megerősítésre került, hogy akut coronariaszindrómában (ACS) az esemény után minél korábban, már 1-4 nappal később, nagy dózisú statin adására kerüljön sor (I/A ajánlás), amit 4-6 hét múlva történt vérvétel alapján kell a célértékek elérésének függvényében módosítani (IIa/C). Csak mellékhatások megnövekedett kockázatakor ajánlják kisebb adagú statinterápia mérlegelését (például idős betegeken, máj- és veseelégtelenség esetén). Percutan intervenció (PCI) előtt is (elektív formában vagy NSTEMI esetén), metaanalízis kedvező eredményeire hivatkozva mérlegelendő a nagy dózisú statin a beavatkozás körüli szívinfarktus gyakoriságának csökkentésére (IIa/A) [4].

Az irányelvek egyértelmű állásfoglalása ellenére a Nemzeti Szívinfarktus Regiszter 2016-ban közölt adatai szerint az évi mintegy 15 ezer magyarországi ACS-es betegből csak $88 \%$ kap statint $[5,6]$. Rosenson és mtsai adatai szerint 8762 amerikai, ACS miatt kezelt beteg 27\%-a ment haza a kórházból nagy dózisú statin javaslatával [7].

Osztályunkon sok éve figyelmet fordítunk a lipidcsökkentés minőségére, az irányelveknek megfelelő kezelésre. Eredményeinkről több közleményben számoltunk be [8-10]. Jelen retrospektív vizsgálatunkban arra kerestünk választ, hogy az ACS miatt PCI-n átesett betegeink milyen lipidcsökkentő (statin-) javaslattal hagyták el osztályunkat, és igyekeztünk felmérni a fél- és egyéves ellenőrzések során az 1,8 mmol/1 LDL-C-célérték elérési arányát is.

\section{Betegek és módszer}

A Békés Megyei Központi Kórház Pándy Kálmán Tagkórháza Kardiológiai Osztályának Invazív Részlegén a 2015-ben ACS miatt PCI-n átesett betegek körében retrospektív adatgyưjtést végeztünk. Elemeztük a kórházi elbocsátáskor alkalmazott terápiát. Megnéztük, hogy osztályunkról milyen lipidcsökkentővel engedtük haza betegeinket, és a rendelkezésre álló adatbázisokban vizsgáltuk azt is, hogy az esemény után fél és egy évvel milyen lipidértékek voltak, és a páciensek milyen gyógyszeres terápiában részesültek. A jelen közlés csak a 
A 2015-ben percutan coronariaintervención átesett betegek életkori és nemi megoszlása az akut coronariaszindróma típusa szerint

\begin{tabular}{lcccc}
\hline & Összes & STEMI & NSTEMI & ISAP \\
\hline Betegszám & 454 & 112 & 239 & 103 \\
\hline $\begin{array}{l}\text { Betegszám } \\
(\%)\end{array}$ & 100 & 24,7 & 52,6 & 22,7 \\
\hline $\begin{array}{l}\text { Életkor } \\
(\text { év } \pm \text { SD })\end{array}$ & $68,9 \pm 12,4$ & $68,6 \pm 13,7$ & $69,6 \pm 12,2$ & $67,5 \pm 11,3$ \\
\hline Férfiak & 301 & 72 & 163 & 66 \\
\hline Férfiak\% & 66,3 & 64,3 & 68,2 & 64,1 \\
\hline $\begin{array}{l}\text { Életkor } \\
(\text { év } \pm \text { SD) }\end{array}$ & $66,7 \pm 12,0$ & $65,8 \pm 13,8$ & $67,7 \pm 11,7$ & $65,2 \pm 10,4$ \\
\hline Nók & 153 & 40 & 76 & 37 \\
\hline Nók $(\%)$ & 33,7 & 35,7 & 31,8 & 35,9 \\
\hline $\begin{array}{l}\text { Életkor } \\
(\text { év } \pm \text { SD) }\end{array}$ & $73,1 \pm 12,1$ & $73,4 \pm 12,3$ & $73,6 \pm 12,3$ & $71,7 \pm 11,8$ \\
\hline
\end{tabular}

ISAP $=$ instabil angina pectoris; NSTEMI = nem ST-elevatiós myocardialis infarctus; $\mathrm{SD}=$ standard deviáció $;$ STEMI = ST-elevatiós myocardialis infarctus

lipidcsökkentő kezelést elemzi, s későbbre tervezzük, hogy beszámolunk a túlélést javító egyéb gyógyszerek alkalmazási gyakoriságának vizsgálatáról is.

A vizsgálat lefolytatásához a Békés Megyei Központi Kórház Pándy Kálmán Tagkórháza Intézményi Humán Kutatásetikai Bizottsága engedélyt adott.

A statisztikai elemzéseket az SPSS 16.0 for Windows (SPSS, Chicago, IL, USA) programcsomag segítségével végeztük. A kategorikus adatokat abszolút számokban és százalékokban, illetve a folyamatos változókat normális eloszlás esetén számtani középpel és standard deviációval, nem normális eloszlás esetén pedig medián és interkvartilis (IQ) tartománnyal ábrázoltuk. A kate-
2. táblázat

A betegek statinterápiája hazaengedéskor az akut coronaria szindróma típusa egyes formáiban

\begin{tabular}{lcccc}
\hline & $\begin{array}{c}\text { Összes } \\
(\mathrm{n}=454)\end{array}$ & $\begin{array}{c}\text { STEMI } \\
(\mathrm{n}=112)\end{array}$ & $\begin{array}{c}\text { NSTEMI } \\
(\mathrm{n}=239)\end{array}$ & $\begin{array}{c}\text { ISAP } \\
(\mathrm{n}=103)\end{array}$ \\
\hline $\begin{array}{l}\text { Nem kapott } \\
\text { statint }(\mathrm{n} / \%)\end{array}$ & $33 / 7,2$ & $11 / 9,9$ & $14 / 5,9$ & $8 / 7,8$ \\
\hline $\begin{array}{l}10 \mathrm{mg} \text { rozuvastatin } \\
(\mathrm{n} / \%)\end{array}$ & $4 / 0,9$ & $1 / 0,9$ & $3 / 1,3$ & 0
\end{tabular}

$(\mathrm{n} / \%)$

\begin{tabular}{lcccc}
\hline $\begin{array}{l}20 \text { vagy } 40 \mathrm{mg} \\
\text { rozuvastatin }(\mathrm{n} / \%)\end{array}$ & $378 / 83,2$ & $92 / 82,1$ & $198 / 82,8$ & $88 / 85,4$ \\
\hline $\begin{array}{l}40 \text { vagy } 80 \mathrm{mg} \\
\text { atorvastatin }(\mathrm{n} / \%)\end{array}$ & $13 / 2,9$ & $3 / 2,6$ & $7 / 2,9$ & $3 / 2,9$ \\
\hline $\begin{array}{l}\text { Statin + ezetimib } \\
\text { (szám/\%) }\end{array}$ & $26 / 5,8$ & $5 / 4,5$ & $17 / 7,1$ & $4 / 3,9$ \\
\hline
\end{tabular}

ISAP = instabil angina pectoris; NSTEMI = nem ST-elevatiós myocardialis infarctus; STEMI = ST-elevatiós myocardialis infarctus

gorikus adatokat Fisher-egzakt teszttel elemeztük; a folytonos változók összehasonlítása nem paraméteres Mann-Whitney-féle U-teszttel történt. Minden feltüntetett p-érték kétoldalas, és a p<0,05-ot tekintettük szignifikánsnak.

\section{Eredmények}

Osztályunkon 2015-ben 454 betegen történt PCI ACS miatt. A páciensek több mint felénél nem ST-elevatiós myocardialis infarctus (NSTEMI), kb. negyedüknél ST-elevatiós infarctus (STEMI) és 22,7\%-uknál instabil angina pectoris (ISAP) miatt (1. táblázat).

A 454 beteg átlagos életkora $( \pm$ SD) 68,9 $\pm 12,4$ év volt; a különböző ACS-formák között nem mutatkozott szignifikáns különbség. A 301 férfi $(66,3 \%)$ életkora $( \pm$ SD ) $66,7 \pm 12,0$ év volt, a nóké $73,1 \pm 12,1$ (p<0,0001).

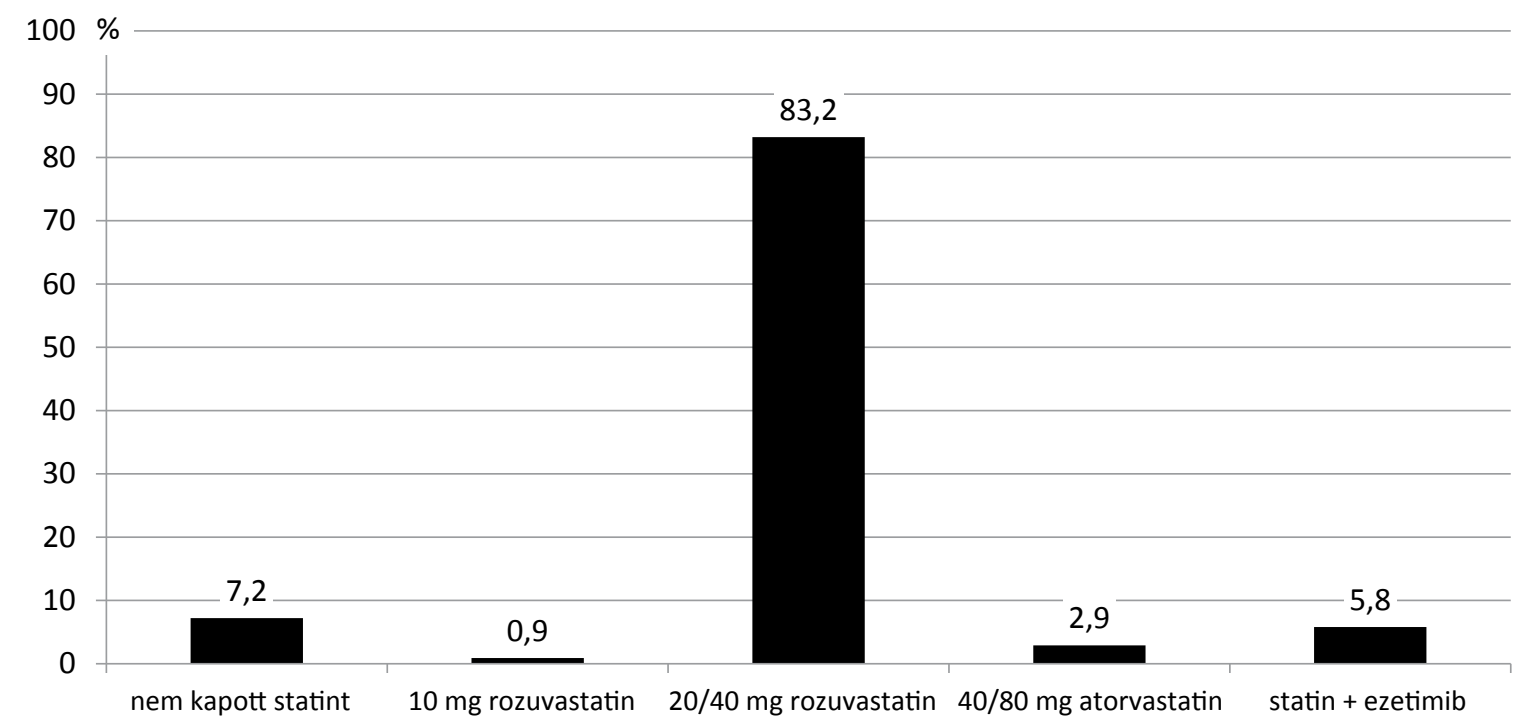

1. ábra $\quad$ A 2015-ben a gyulai Kardiológiai Osztályon akut coronariaszindróma miatt kezelt betegek elbocsátásakor javasolt lipidcsökkentő terápia alkalmazási gyakorisága $(\%)$ 
3. táblázat |A vizsgálatokon megjelenő betegek lipidcsökkentő terápiája fél év és egy év után

\begin{tabular}{lcc}
\hline & Fél év (220 fö) & Egy év (292 fó) \\
\hline $\begin{array}{l}10 \mathrm{mg} \text { rozuvastatin } \\
(\mathrm{n} / \%)\end{array}$ & $15 / 6,8$ & $23 / 7,8$ \\
\hline $20-40 \mathrm{mg}$ rozuvastatin $(\mathrm{n} / \%)$ & $164 / 74,6$ & $193 / 66,0$ \\
\hline 40 vagy $80 \mathrm{mg}$ atorvastatin $(\mathrm{n} / \%)$ & $9 / 4,1$ & $14 / 4,8$ \\
\hline Statin + ezetimib $(\mathrm{n} / \%)$ & $32 / 14,5$ & $62 / 21,4$ \\
\hline
\end{tabular}

Vizsgálatunk fó célkitûzése a kórházi elbocsátáskor alkalmazott lipidcsökkentő kezelés felmérése volt, amely az intervención átesett összes beteg esetében lehetségesnek bizonyult; az eredmények a 2. táblázatban láthatók. Szembetúnő a nagy adagú rozuvastatin alkalmazásának dominanciája (1. ábra) (37l beteg 40-40 mg-ot kapott). A betegek 7,2\%-a nem kapott statint az elbocsátáskor, ez magas számnak tû́nhet. Megnéztük külön, hogy mi magyarázza ezt. Hat olyan beteg volt $(1,3 \%)$, aki igen idős kora és általános állapota miatt statinjavaslat nélkül távo- zott otthonába; a statint nem kapó többi páciens a kórházban töltött időszak alatt meghalt. A 3. táblázat a lipidcsökkentő terápia fél és egy év utáni eredményét mutatja be. A betegek közel harmadának a terápiáját sajnos nem ismerjük, mert az adatbázisban nem volt erre utaló adat, és ellenőrzésen nem jelentek meg. Az összes 454 ACS-es közül 42 beteg egy éven belül meghalt, 10 beteg pedig nem a mi ellátási területünkön élt (egy külföldi volt, a többi pedig az ország másik részéról került akut ellátásra Gyulán). Ezt az összesen 52 föt levonva a 454-ből egy év után, 402 beteget véve 100\%-nak, 73\%ról volt terápiás adatunk. Látható, hogy azon betegek körében, akik jártak ellenőrzésre, továbbra is a nagy hatékonyságú lipidcsökkentés dominál. Fél évnél 154 betegre vonatkozóan volt lipideredményünk (ezek az adatok a 4. táblázatban láthatók), de 220-nál tudtuk, hogy milyen lipidcsökkentő kezelést kapott - ennek adatai a 3. táblázat fél évre vonatkozó oszlopában szerepelnek. A féléves LDL-C-szintek mellett a 4. táblázat az egyéves adatokat is szemlélteti (medián és interkvartilis tartomány) az összes beteg, férfiak és nők vonatkozásában, valamint a három ACS-formát illetően külön is. Látható

4. táblázat | A betegek LDL- és összkoleszterinszintje fél év és egy év után a nemek és az akut coronariaszindróma típusa szerint

\begin{tabular}{|c|c|c|c|}
\hline & Féléves kontroll & Egyéves kontroll & \\
\hline Összes beteg (fö) & 154 & 292 & \\
\hline LDL-koleszterin (mmol/l, medián [IQ-tartomány]) & $1,90(1,40-2,20)$ & $2,00(1,48-2,43)$ & $\mathrm{p}=0,01$ \\
\hline Összkoleszterin (mmol/l, medián [IQ-tartomány]) & $3,50(3,03-4,26)$ & $3,72(3,14-4,44)$ & $\mathrm{p}=0,01$ \\
\hline $1,8 \mathrm{mmol} / 1$ elérése $(\%)$ & 48,7 & 37,3 & $\mathrm{p}=0,01$ \\
\hline Férfiak (fó) & 108 & 210 & \\
\hline LDL-koleszterin (mmol/l, medián [IQ-tartomány]) & $1,90(1,36-2,15)$ & $2,00(1,37-2,30)$ & $\mathrm{p}=0,01$ \\
\hline Összkoleszterin (mmol/l, medián [IQ-tartomány]) & $3,46(2,95-4,07)$ & $3,64(3,00-4,37)$ & $\mathrm{p}=0,01$ \\
\hline $1,8 \mathrm{mmol} / 1$ elérése $(\%)$ & 50 & 40,6 & $\mathrm{p}=0,01$ \\
\hline Nók (fó) & 46 & 82 & \\
\hline LDL-koleszterin (mmol/1, medián [IQ-tartomány]) & $1,85(1,42-2,40)$ & $2,00(1,73-2,42)$ & $\mathrm{p}=0,01$ \\
\hline Összkoleszterin (mmol/1, medián [IQ-tartomány]) & $3,71[3,13-4,50)$ & $4,04(3,45-4,54)$ & $\mathrm{p}=0,01$ \\
\hline $1,8 \mathrm{mmol} / 1$ elérése $(\%)$ & 48 & 28,9 & $\mathrm{p}=0,01$ \\
\hline STEMI (fo) & 42 & 68 & \\
\hline LDL-koleszterin (mmol/l, medián [IQ-tartomány]) & $1,84(1,30-2,10)$ & $1,98(1,13-2,06)$ & $\mathrm{p}=0,01$ \\
\hline Összkoleszterin (mmol/1, medián [IQ-tartomány]) & $3,49(2,99-4,13)$ & $3,67(3,00-4,28)$ & $\mathrm{p}=0,01$ \\
\hline 1,8 mmol/1 elérése (\%) & 50,0 & 48,4 & $\mathrm{p}=0,05$ \\
\hline NSTEMI (fö) & 76 & 154 & \\
\hline LDL-koleszterin (mmol/l, medián [IQ-tartomány]) & $1,90(1,40-2,27)$ & $2,00(1,73-2,78)$ & $\mathrm{p}=0,01$ \\
\hline Összkoleszterin (mmol/1, medián [IQ-tartomány]) & $3,50(3,00-4,31)$ & $3,78(3,22-4,54)$ & $\mathrm{p}=0,01$ \\
\hline $1,8 \mathrm{mmol} / \mathrm{l}$ elérése $(\%)$ & 47,4 & 31,0 & $\mathrm{p}=0,01$ \\
\hline ISAP (fö) & 36 & 70 & \\
\hline LDL-koleszterin (mmol/l, medián [IQ-tartomány]) & $1,85(1,25-2,27)$ & $2,00(1,29-2,40)$ & $\mathrm{p}=0,01$ \\
\hline Összkoleszterin (mmol/1, medián [IQ-tartomány]) & $3,59(3,06-4,41)$ & $3,63(3,06-4,45)$ & $\mathrm{p}=0,01$ \\
\hline 1,8 mmol/1 elérése (\%) & 50,0 & 40,6 & $\mathrm{p}=0,01$ \\
\hline
\end{tabular}

IQ = (interquartile) interkvartilis; ISAP $=$ instabil angina pectoris; NSTEMI $=$ nem ST-elevatiós myocardialis infarctus; STEMI $=$ ST-elevatiós myocardialis infarctus 
továbbá az 1,8 mmol/1 LDL-C-célérték elérésének aránya is. Ezeket a táblázatban annak a 154 vagy 292 betegnek az arányában adtuk meg, akiktől tényleges adatot tudtunk nyerni az adott időszakban. Ha a viszonyítást az egy év után még életben levő és a mi ellátási területünkön élő 402 beteget 100\%-nak véve végezzük, a féléves célértékelérési arány 48,7\% helyett 18,7\%, az egyéves pedig 37,3\% helyett 27,1\% lenne. A táblázatban megfigyelhető, hogy az egyéves eredmények a legtöbb esetben szignifikánsan rosszabbak. A férfiak és a nők adatai között nem volt szignifikáns különbség sem fél év, sem pedig egy év elteltével. Szignifikáns eltéréstől mentes a három ACS-formát összehasonlítva az LDL-C- és célértékelérési arány. Annak a 154 betegnek, akiknek a féléves LDL-C-értéke látható a 4. táblázatban, a kiindulási LDL-C (medián [IQ-tartomány]) 3,30 (2,30-4,11) $\mathrm{mmol} / \mathrm{l}$ volt, egy év után pedig $2,00(1,40-2,21)$ mmol/l; ez utóbbi nagyon hasonló a 292 beteg egyéves adatához.

\section{Megbeszélés}

Chen és mtsai 1999-ben az akut myocardialis infarctus (AMI) ellátását elemezték az Amerikai Egyesült Államok kórházaiban (ott szokás rangsorolni a kórházakat és kiadni szakmánként a „Best Hospitals” sorrendet). A legjobbnak tartott intézményekben valóban kedvezőbb volt az AMI miatti halálozási arány, mint a nem odasorolt, de hasonlóan felszerelt vagy gyengébben felszerelt kórházakban, és ennek okaként nem azt jelölték meg, hogy ott jobbak a technikai feltételek, hanem azt, hogy következetesebben alkalmazták az akkor ajánlott gyógyszeres kezelést [11]. A terápiás ajánlások sokat változtak az időközben eltelt közel két évtized alatt, de azok betartása, véleményünk szerint, fontosabb, mint valaha. Az elmúlt időszakra a revascularisatio elterjedése mellett jellemző a lipidcsökkentő kezelés előtérbe kerülése. Annak ellenére, hogy ez a nemzetközi és a hazai irányelvekben kiemelt helyen szerepel, nagy ür van a lehetôségek és a tényleges napi gyakorlat között.

A korábbi magyar felmérésekben az 1,8 mmol/1 LDLC-célértéket csak a betegek 19-20\%-a érte el [12-15]. $\mathrm{Az}$ Európa-szerte ischaemiás szívbetegségben (ISZB) szenvedő betegeken történt EUROASPIRE IV-ben az 1,8 mmol/1 LDL-C-t illetően a férfiak 18\%-a, a nók 17\%-a volt célértéken (2. ábra) [16]. A Dyslipidemia International Study (DYSIS) II-ben az ACS-es betegek kevesebb mint 30\%-a érte el az 1,8 mmol/1 LDL-C-célértéket [17]. Az eredmények azt mutatják, hogy a lipidcsökkentésben rejlő preventív lehetőségek, az irányelvek ajánlásai ellenére, nem kerülnek megvalósításra, amivel az orvosok gyakran nincsenek tisztában: azt gondolják, hogy a célértékek elérésében sokkal jobb eredményeik vannak. Németországban történt felmérésben 539 orvos 2625 igen nagy kockázatú betegének statinkezelését elemezve az 1,8 mmol/1 LDL-C-célértéket a betegek 7,5-15,2\%-a érte el, miközben a precíznek tartott német orvosok azt gondolták, hogy azok elérése 62-63\%-ban történik meg [18].

Megfelelő együttmúködés esetén pedig a statin - és szükség szerint ezetimib - adásával a betegek túlnyomó többségében a célértékek elérhetők lennének. Cannon és mtsai a napi gyakorlat adatai alapján közel 400 ezer, lipidcsökkentőt szedő, atheroscleroticus érbetegségben szenvedő betegen modellezték az 1,8 mmol/1 LDL-Ccélérték elérésének esélyeit. Eredményeik alapján nagy intenzitású statin adásával az esetek 70\%-ában ez megvalósulna. Az ezetimib hozzáadásával az arány $86 \%$-ra nőhet, és csupán 14\%-ban lenne szükség PCSK9-gátló adására [19].

Retrospektív vizsgálatunk szerint betegeink túlnyomó többsége megfelelő lipidcsökkentő terápiás ajánlással távozott haza a kórházból. Több mint $80 \% 40 \mathrm{mg}$ rozuvastatint kapott, 4-7\% pedig ezetimibes kombinációt. Ez

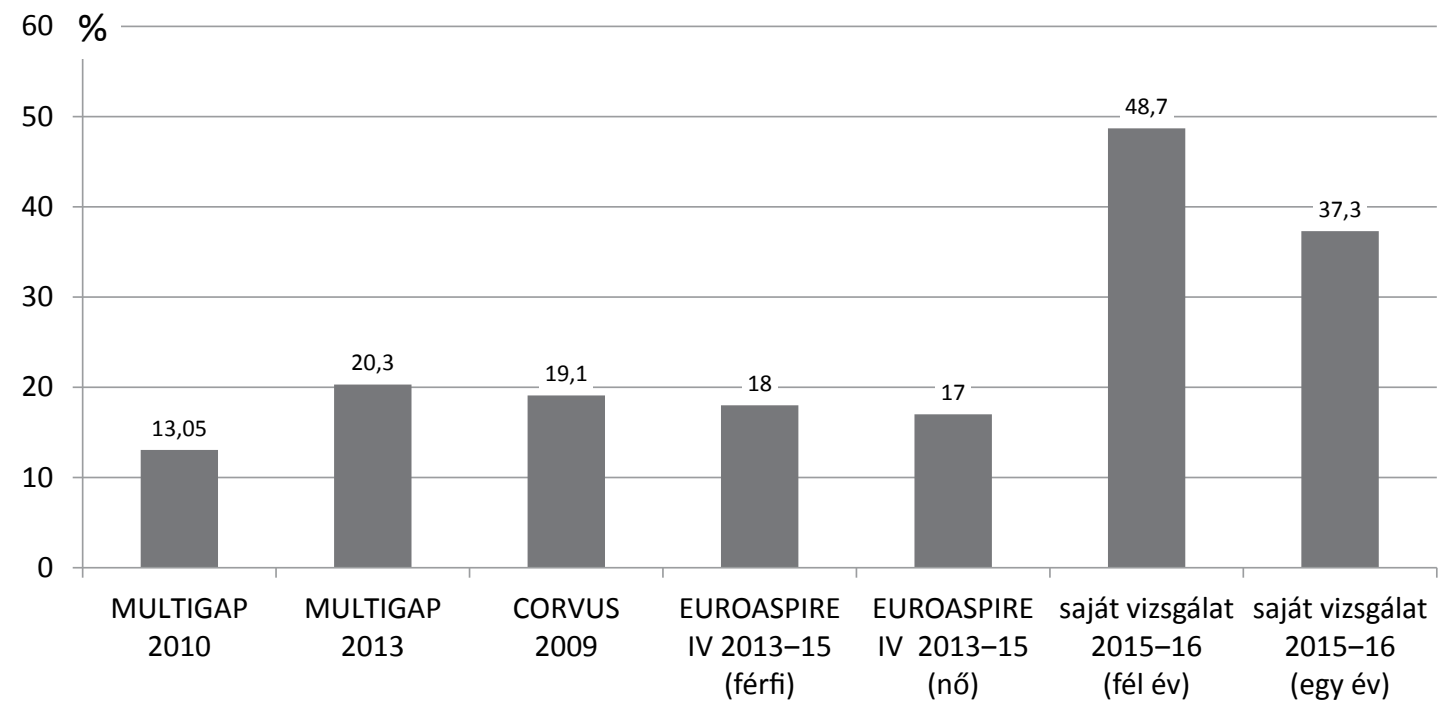

2. ábra |Az 1,8 mmol/1 LDL-koleszterin-célértéket elérők aránya (\%) magyar és európai adatok alapján, valamint a jelen vizsgálatban 
utóbbinak az arányát azért tartjuk elfogadhatónak, mert egyrészt a nagy adagú statin adása megfelel az irányelveknek, másrészt a magyarországi elöírások csak olyan esetben teszik lehetővé a kombináció alkalmazását, amikor a tolerált legnagyobb statinadagok mellett a célértéket nem érjük el. ACS miatti elbocsátáskor ez csak korábbi statinszedéssel kapcsolatos intoleranciaproblémák esetén valósulhat meg. Alapvetően azt mondhatjuk, hogy a hazaengedéskor javasolt, az irányelveknek megfelelő nagy dózisú statin az esetek 9/10-ében megvalósul, amivel elégedettek lehetünk.

A fél és az egy év utáni LDL-C-átlag hízelgően szépnek tûnhet (1,90 és 2,00 mmol/l), de nem szabad megfeledkeznünk arról, hogy ez az ellátási területünkön élő 402 fónek csak a 73\%-ára vonatkozó adatok alapján került megállapításra. Nagyon valószínü, hogy az egy évig a kórházban kontrollvizsgálaton nem jelentkezők adatai lényegesen rosszabb képet mutatnának.

Mindenesetre a féléves ellenőrzés során a 152 betegnél talált 49\%-os és az egy év után a 292 betegnél talált 37,3\%-os 1,8 mmol/1 LDL-C-célérték-elérési arány a korábbi magyar felmérésekben leírt 19-20\%-hoz [1215] képest lényegesen magasabb (2. ábra). Ugyanakkor ha a 402 foore vonatkoztatjuk a célértéket elérők arányát, akkor az 18,7\%, illetve 27,1\% lenne. Mindazonáltal a kontroll számára elérhetetlen betegek nagy száma és az, hogy egy év után már magasabb az LDL-C, mint fél év után, arra hívja fel a figyelmet, hogy az időszakos ellenőrzésekre és betegvisszahívásokra az eddiginél nagyobb hangsúlyt kellene helyezni. Tomcsányi az Országos Egészségpénztár adatai alapján végzett vizsgálatában a statinkezelésben, hozzánk hasonlóan, a nagy hatékonyságú adagok dominanciáját írta le, és az idő múlásával ott is nőtt az elégtelen vagy a kezelésben egyáltalán nem részesülők aránya [20].

Vizsgálatunk hiányossága, hogy a felmérést egy centrumban végeztük. A megye kórházaiból az ACS-es betegek Gyulán kerülnek primer ellátásra. Nem kerestük meg az ilyen diagnózissal a vizsgált időszakban máshol kezelt Békés megyei betegeket. Saját munkánkat ellenőriztük ebben a retrospektív elemzésben. Limitáló tényező, hogy az utánkövetés csupán a betegek 73\%-ánál volt lehetséges a kórházi adatbázisokban.

Az a tény, hogy azok körében, akik ellenőrzésre járnak, a fél év és az egy év utáni LDL-C-átlag megközelíti a célértéket, de egy év után már magasabb, mint fél év után, arra hívja fel a figyelmet, hogy a jövőben nagyobb gondot kell fordítani az egyre növekvő számú revaszkularizált beteg szisztematikus ellenőrzésére. A jó együttmúködésû betegeknek jobbak a hosszú távú életkilátásai [6]. Törekednünk kell arra, hogy minden ilyen beteg időszakos vizsgálata megtörténjen, hogy hazaengedéskor kapjon időpontot a következő megjelenésre. Csak az ellenőrzések során jobban megvalósuló előírt terápia következetes betartása által remélhető, hogy azok a túlélési lehetőségek, amelyek a PCI által a betegek számára elvileg adottak, hosszabb távon is megvalósuljanak.
Anyagi támogatás: A közlemény megírása, illetve a kapcsolódó kutatómunka anyagi támogatásban nem részesült.

Szerzői munkamegosztás: M. L.: A téma felvetése, a vizsgálat megtervezése, a kézirat megszövegezése. N. M., B. M.: Adatgyújtés. D. Gy.: Irodalmazás, statisztikai vizsgálatok. B. Cs.: A kézirat átnézése. K. A.: A kézirat átnézése, az ábrák szerkesztése. J. Z.: A kézirat véleményezése. A cikk végleges változatát valamennyi szerző elolvasta és jóváhagyta.

Érdekeltségek: A szerzőknek nincsenek érdekeltségeik.

\section{Irodalom}

[1] Kannel WB, Dawber TR, Friedman GD, el al. Risk factors in coronary heart disease. An evaluation of several serum lipids as predictors of coronary heart disease: The Framingham Study. Ann Intern Med. 1964; 61: 888-899.

[2] Ference BA, Ginsberg HN, Graham I, et al. Low-density lipoproteins cause atherosclerotic cardiovascular disease. 1. Evidence from genetic, epidemiologic, and clinical studies. A consensus statement from the European Atherosclerosis Society Consensus Panel. Eur Heart J. 2017; 38: 2459-2472.

[3] The recommendations of the 6th Hungarian Cardiovascular Consensus Conference. [A VI. Magyar Kardiovaszkuláris Konszenzus Konferencia ajánlásai.] Metabolizmus 2015; 13: 1-55. [Hungarian]

[4] Catapano AL, Graham I, De Backer G, et al. 2016 ESC/EAS guidelines for the management of dyslipidaemias. Eur Heart J. 2016; 37: 2999-3058.

[5] Jánosi A. Myocardial infarction - 2016: frequency, medical care, prognosis. [Szívinfarktus 2016: gyakoriság, ellátás, prognózis.] Cardiol Hung. 2017; 47: 336-340. [Hungarian]

[6] Jánosi A. Ofner P, Kiss Z, et al. Adherence to medication after myocardial infarction and its impact on outcome: a registrybased analysis from the Hungarian Myocardial Infarction Registry. [Szívinfarktust túlélt betegek terápiahűsége a másodlagos megelőzés szempontjából fontos gyógyszeres kezelésekhez.] Orv Hetil. 2017; 158: 1051-1057. [Hungarian]

[7] Rosenson RS, Kent ST, Brown TM, et al. Underutilization of high-intensity statin therapy after hospitalization for coronary heart disease. J Am Coll Cardiol. 2015; 65: 270-277.

[8] Dani Gy, Nagy E, Hajdara I, et al. Main features of the care of patients with multiplex cerebral infarction. [A multiplex agyi infarktusos betegek ellátásának jellemzői.] Metabolizmus 2007; 5: 136-140. [Hungarian]

[9] Márk L, Dani Gy, Kiss Z, et al. A change of attitude in lipidology, achievement of target levels. What comes next? [Szemléletváltozás a lipidológiában, a célértékek elérése. Hogyan tovább?] Orv Hetil. 2008; 149: 1731-1736. [Hungarian]

[10] Katona A, Márk L, Nagy E, et al. The change in hospital care of patients suffering from acute myocardial infarction with ST elevation during the last decades in the county hospital, Gyula from "armchair" to the hemodynamic laboratory. [Az ST szakasz elevációval járó szívizominfarktusos betegek ellátásának változása az elmúlt évtizedekben a gyulai megyei kórházban - a „karosszéktől” a szívkatéteres laboratóriumig.] Cardiol Hung. 2017; 47: 329-335. [Hungarian]

[11] Chen J, Radford MJ, Wang Y, et al. Do "America's Best Hospitals" perform better for acute myocardial infarction? N Engl J Med. 1999; 340: 286-292.

[12] Márk L, Reiber I, Paragh Gy, et al. Lipid lowering therapy MULTI GAP 2012. Therapeutic compliance of the patients, statin persistence. [Lipidcsökkentő kezelés - MULTI GAP 2012. A 
betegek terápiás együttmúködése, statin-perzisztencia.] Metabolizmus 2013; 11: 167-172. [Hungarian]

[13] Márk L, Reiber I, Bajnok L, et al. The practical benefit of switch ing to rosuvastatin from other statins in high risk patients. The CORVUS (COntrolled TaRgets for High Vascular Risk Patients Using Effective Statins) study. [A rosuvastatinra váltás gyakorlati haszna nagy kockázatú, statint szedó betegek esetén. A CORVUS vizsgálat (COntrolled TaRgets for High Vascular Risk Patients Using Effective Statins).] Metabolizmus 2010; 8: 269-273. [Hungarian]

[14] Mark L, Reiber I, Bajnok L, et al. The effect of switching to the high-efficient rosuvastatin on the success of lipid lowering therapy in high risk patients. The CORVUS (Controlled Targets for High Vascular Risk Patients Using Effective Statins) Study. Pharm Anal Acta 2013; 4: 267.

[15] Simonyi G. Lipid-lowering therapy and patient adherence in the MULTI GAP 2013 trial. [Lipidcsökkentő terápia és betegadherencia a MULTI GAP 2013 vizsgálat tükrében.] Orv Hetil. 2014; 155: 669-675. [Hungarian]

[16] Kotseva K, Wood D, De Bacquer D, et al., on behalf of the EU ROASPIRE Investigators. EUROASPIRE IV: A European Society of Cardiology survey on the lifestyle, risk factor and thera- peutic management of coronary patients from 24 European countries. Eur J Prev Cardiol. 2016; 23: 636-648.

[17] Ferrières J, Rouyer MV, Lautsch D, et al., for the Dyslipidemia International Study (DYSIS) II France Study Group. Suboptimal achievement of low-density lipoprotein cholesterol targets in French patients with coronary heart disease. Contemporary data from the DYSIS II ACS/CHD study. Arch Cardiovasc Dis. 2017; 110: 167-178.

[18] Laufs U, Karmann B, Pittrow D. Atorvastatin treatment and LDL cholesterol target attainment in patients at very high cardiovascular risk. Clin Res Cardiol. 2016; 105: 783-790.

[19] Cannon CP, Khan I, Klimchak A, et al. Simulation of lipid-lowering therapy intensification in a population with atherosclerotic cardiovascular disease. JAMA Cardiol. 2017; 2: 959-966.

[20] Tomcsányi J. Adherence to statins in patients with myocardial infarction in Hungary. [Statin gyógyszerszedési gyakorlat myocardialis infarctus után Magyarországon.] Orv Hetil. 2017; 158: 443-446. [Hungarian]

(Márk László dr., Gyula, Semmelweis u. 1., 5700 e-mail: mark@pandy.hu)

\section{Pályázati felhívás}

Professzor Dr. Fehér János munkássága, szakmai és erkölcsi hagyatéka páratlan és maradandó az orvostudományban. Ezért a Semmelweis Egyetem Általános Orvostudományi Kar II. sz. Belgyógyászati Klinika volt igazgatója, „A hepatológiai szabad gyökös és immunológiai vonatkozásai" című program vezetöjének, az Orvosi Hetilap föszerkesztöjének emlékére Alapitvány létesült. Az alapítványt a Fővárosi Bíróság 2011. március 7-én 11.335. sorszám alatt nyilvántartásba vette.

Dr. Fehér János Emlékére Alapítvány fö célja: a belgyógyászat, különösen a hepatológia szabad gyökös és immunológiai vonatkozásai témakörök kutatásának fejlesztése, támogatása, illetve ösztönzése oly módon, hogy a fiatal egyetemi oktatók és hallgatók az alapitvány kamatából részesüljenek. Az alapitvány célja olyan orvosok, PhD-hallgatók dijazása, akik kiemelkedő tudományos munkát végeznek és eredményeiket az Orvosi Hetilapban publikálják.

A dolgozatot „Dr. Fehér János pályázat” megjelölésével kell benyújtani.

A pályázatot 2018. április 15-ig lehet beküldeni a Kuratórium elnökének (Dr. Hagymási Krisztina) vagy titkárának (Dr. Lengyel Gabriella) - Semmelweis Egyetem, II. sz. Belgyógyászati Klinika, 1088 Budapest, Szentkirályi u. 46. címre.

A pályázathoz mellékelni kell a pályázó önéletrajzát és a dolgozatot.

A dijak odaitéléséröl a kuratórium dönt. A dijj átadására a Markusovszky ünnepségen kerül sor. Az ünnepségen a nyertes pályázó maximum 5-10 perces előadásban foglalja össze az eredményeit. 